\title{
MICHAŁA KRZYSZTOFA HANOWA WSPOMNIENIE ZASŁUG PROTOBIBLIOTEKARZY GDAŃSKICH XVII I XVIII WIEKU
}

Zainteresowania bibliologiczne, w tym o charakterze badawczym i naukowym, pojawity się w Prusach Królewskich, przede wszystkim w Gdańsku, Toruniu i Elblągu, już w pierwszej połowie XVIII wieku, jako rezultat recepcji haseł oświeceniowych, docierających tam głównie za pośrednictwem niemieckich uniwersytetów. Wyrażały się one w publikacjach bibliograficznych, biobibliograficznych, a także z zakresu historii ksią̇ki i bibliotek, które wychodziły spod pióra miejscowych autorów, takich np. jak Gabriel Groddeck, Walenty Schlieff, Samuel Joachim Hoppius, Dawid Braun, Efraim Oloff, Efraim Praetorius, Andrzej i Krystian Fryderyk Charitiusowie, Jakub Henryk Zernecke, Aleksander Mikołaj Tolckemit, Jan Daniel Hoffmann, Piotr Jaenichius, Jerzy Daniel Seyler, Paweł Pater, Jan Ludwik Nicolai, Jan Lange czy Jan Samuel Sammet, by wymienić tylko najwybitniejszych ${ }^{1}$. Do tego grona oświeceniowych uczonych, określanych mianem "literati" lub "Gelehrte", należał także Michał Krzysztof Hanow (1695-1773), wyróżniający się rozlegrą erudycją $w$ wielu dziedzinach wiedzy, polihistor $z$ rzadko spotykaną inwencją $i$ intuicją badawczą.

Erudycja naukowa Hanowa wynikała z osobistych uzdolnień i gruntownych studiów uniwersyteckich, odbytych w latach 1716-1720 w Królewcu, Wittenberdze i Lipsku w zakresie teologii, filozofii, prawa, literatury klasycznej, a także nauk przyrodniczych, medycyny, matematyki i języków obcych. W wieku 25 lat uzyskał prawo wykładania na uniwersytecie filozofii i retoryki. W 1727 roku został zaproszony do Gdańska, gdzie powierzono mu stanowisko profesora filozofii w Gimnazjum Akademickim. Tam szybko dał się poznać jako aktywny i pelen innowacyjnych pomysłów naukowiec, uprawiający wiedzę w duchu oświeceniowej filozofii Chrystiana Wolffa i jednocześnie pobudzający do twórczej działalności miejscowe środowisko intelektualne. Dużo pisał i publikował, redagował czasopisma, prowadził nowatorskie badania statystyczne i obserwacje meteorologiczne, zajmowal się krytycznymi edycjami źródet historycznych, brał żywy udział w pracach Towarzystwa Przyrodniczego, utrzymywał kontakty z uczonymi z głębi kraju i zagraniczny$\mathrm{mi}^{2}$.

Wraz z obowiazkami profesora filozofii powierzono Hanowowi stanowisko bibliotekarza w Bibliotece Rady Miasta, która to książnica mieściła się w budynku Gimnazjum Akademickiego i głównie tej szkole służyła. Łączenie tych dwóch stanowisk było wówczas w Gdańsku zjawiskiem prawie stałym. Zadania bibliote- 
karskie spełniał Hanow w latach 1727-1773, traktując je poważnie i nader odpowiedzialnie, zarówno $w$ codziennej praktyce, jak i w poczynaniach badawczych w zakresie wiedzy o ksiażce i bibliotece. Troszczyl się o wzbogacanie zasobów i poszerzanie profilu gromadzenia materiałów bibliotecznych, odrabiał zaległości inwentaryzacyjne, zapoczątkował alfabetyczne katalogowanie zbiorów, powiększył pomieszczenie książnicy o salę dawnego Collegium Anatomicum, przekazał tej librarii własny księgozbiór (około 3000 tomów) wraz z kolekcją portretów, w której znalazł się też jego własny portret wykonany przez Jakuba Wessela. Nie zaniedbywal przy tym pracy naukowej, poszerzając swe zainteresowania w kierunku historii książki w Gdańsku i w innych miastach Prus Królewskich. W redagowanym przez siebie czasopiśmie „Nützlicher Danziger Erfahrungen” zamieszczał informacje bibliograficzne o drukach gdańskich i tam ogłosił pierwsze doniesienie o Jakubie Karweyssem, drukarzu malborskim z końca XV wieku. Hanow był też autorem pionierskiej rozprawy o dziejach sztuki typograficznej w Gdańsku i innych miastach Prus Królewskich ${ }^{3}$. Ważne notatki i spostrzeżenia z zakresu historii książki i oświaty w Prusach Królewskich pozostawił w rękopisie ${ }^{4}$.

W 1758 roku obchodzony był w Gdańsku jubileusz dwuchsetlecia Gimnazjum Akademickiego. Z tej okazji odbyły się liczne imprezy a staraniem i kosztem władz miejskich ukazała się drukiem wytwornie wydana księga pamiątkowa, zatytułowana "Acta jubilaei secundi Gymnasii Gedanensis” (Gdańsk, T.J. Schreiber, $17582^{\circ}$, ss. $40+296+132$ ). Inicjatorem tej publikacji, a także jej redaktorem był Christian Gabriel Schröder, pełniący wówczas funkcje urzędującego burmistrza. Znalazły się w niej rozprawy naukowe, dysertacje, teksty literackie i muzyczne oraz listy gratulacyjne. Jako pozycja 25 zamieszczona została rozprawa Hanowa „Protoscholarcharum et protobibliothecariorum permagnificorum, magnificorum, generosorum maximeque strenuorum Gymnasii Academici Gedanensis meritorum memoria saecularis saeculi ejusdem paucis adumbrata et exhibita ipso Athenaei die natali Idibus Junii mensis Anno Resurectionis Salvatoris 1758". Zajął się w niej autor problemami z dziedziny lokalnej historii oświaty i książki, których przed nim nikt w tym szczególnym aspekcie osobistych dokonań i zasług nie badał i nie opisywał. Motywację wyboru tematu ujawnił w motcie zaczerpniętym z "Annales" Tacyta: „Suum cuique decus posteritas rependit" (IV 35). Kierował się więc szlachetnym dążeniem wynagrodzenia trudów i starań tych ludzi, którzy przez wiele lat przyczyniali się do wzrastania i rozwoju Gimnazjum Akademickiego oraz ulokowanej przy nim Biblioteki Rady Miasta. Odwołanie się do Tacyta, poczytnego wówczas w Polsce, oznaczało też zamiar pisania "sine ira et studio" i oceniania ludzi według ich rzeczywistych zasług.

Rozprawa Hanowa składa się z trzech części. W części pierwszej, mającej charakter wprowadzenia (s. 231-235) i zatytułowanej "De primordio Athenaei Gedanensis", zarysowane zostały geneza i początki szkoły. Część druga (s. 236-255), zatytułowana „De meritis protoscholarcharum elapsi saeculi”, przedstawia w porządku chronologicznym zasługi protoscholarchów, czyli przewodniczacych Collegium Scholarchale. Instytucja Kolegium Szkolnego pojawiła się około 1600 roku i miała z ramienia Rady Miasta nadzorować działalność wszystkich szkół w Gdańsku. Na jej czele stal urzędujący burmistrz jako protoscholarcha a do 
zespołu wchodzili trzej rajcowie jako scholarchowie. Od 1678 roku skład Kolegium uzupełniono dwoma przedstawicielami Drugiego i czteroma przedstawicielami Trzeciego Ordynku ${ }^{5}$. W niniejszych rozważaniach zajmiemy się tylko trzecią częścią rozprawy, zatytułowaną "De meritis protobibliothecariorum saeculi ejusdem" (s. 255-263), ukazującą dokonania protobibliotekarzy, a więc tych członków Collegium Scholarchale, którzy z upoważnienia władz miejskich zajmowali się potrzebami i funkcjonowaniem Biblioteki Rady Miasta. Od około połowy XVII wieku scholarcha oddelegowany do spraw bibliotecznych był tytułowany „protobibliotekarzem”, chociaż spotyka się jeszcze w drugiej połowie tego stulecia synonimiczne określenia, takie jak „praefectus supremus Bibliothecae”, „inspector Bibliothecae" czy „curator Bibliothecae"6. Protobibliotekarze mieli rozległe kompetencje i mogli wywierać duży wpływ na stan i działainość podległej im placówki. Wielu z nich chciało i potrafiło w pelni to wykorzystać.

Rozprawę pisał Hanow jako bibliotekarz z blisko 30-letnią praktyką właśnie w Bibliotece Rady Miasta. Działalność protobibliotekarzy mógł więc prześledzić zarówno na podstawie przechowywanych tam źródeł i opracowań. jak i stanu organizacyjnego książnicy, jej zbiorów oraz wyposażenia w katalogi i sprzęt biblioteczny. Osobiście współpracował jako bibliotekarz aż z sześcioma protobibliotekarzami, od Abrahama Groddecka począwszy a na Janie Hieronimie Broenie skończywszy. Podstawowym źródłem informacji był inwentarz wpływów, założony w 1596 roku przez Daniela Asaricusa, zatytułowany index librorum, a przez Hanowa nazywany też Liber Benefactorum, gdyż notowano tam przede wszystkim dary 7 . Oprócz wpisów książek i innych materiałów oraz pieniędzy przekazywanych Bibliotece, spotyka się w inwentarzu wzmianki dotyczące protobibliotekarzy i ich działań. Często powołuje się Hanow na rozprawę Samuela Schelwiga "De incrementis Bibliothecae Gedanensis epistola et commentatio" (Gdańsk 1677). Schelwig był bibliotekarzem w Bibliotece Rady Miasta w latach 1643-1681 a wspomniana rozprawa to pierwszy zarys dziejów tej książnicy ${ }^{8}$. Wykorzystał też Hanow materiały historyczne publikowane w „Preussische Sammlung” (t. 1-3, Gdańsk 1747-1750), której był redaktorem i wydawcą. Sporadycznie sięgał do tekstów literackich (wiersz Jana Piotra Titiusa sławiący hojność Jana Thiliusa) i do zarządzeń Rady Miasta, odnoszących się do Biblioteki. Sporo uwag i wniosków wysuwał z bezpośredniej obserwacji stanu książnicy.

W omawianej rozprawie zaprezentował Hanow zasługi 16 protobibliotekarzy w kolejności chronologicznej, którzy sprawowali swe funkcje w latach 1655-1758: Adrian Engelcke (1655-1661), Joachim Schrader (1661-1662), Benjamin Engelcke (1662-1665), Chrystian Schroeder (1665-1677), ponownie Benjamin Engelcke (1677-1681), Jan Ernest Schmieden (1681-1692), Daniel Schlieff (1692-1706), Gotfryd Reyger (1706-1717), Jan Gotfryd Diesseldorff (1717-1720), Gabriel Salomon Schumann (1720-1722), Godfryd Bentzmann (1722-1723), Abraham Groddeck (1723-1730), Albert Rosenberg (1730-1749), Jan Zygmunt Ferber (17491751), Jerzy Simon Boemeln (1751-1752), Gabriel Chrystian Schroeder (17521753), Jan Hieronim Broen (1753-1758). Pominall Hanow pierwszego protobibliotekarza Gabriela Schumanna, który pełnił tę funkcję na pewno w 1654 roku. Dowodzą tego teksty okolicznościowe pióra Jerzego Neufelda, opublikowane w 1654 roku z 
okazji zgonu Schumanna, w których określa on zmarłego jako protobibliotekarza. Neufeld był w tym czasie bibliotekarzem, więc w tej sprawie nie mógł się mylić. Pominięcie przez Hanowa nazwiska pierwszego protobibliotekarza mogło wynikać z faktu, że pełnił on tę funkcję bardzo krótko ${ }^{9}$.

Hanow prezentujac protobibliotekarzy pomijał ich biografie, koncentrował się wyłącznie na wymienianiu zasług dla Biblioteki Rady Miasta, tym samym wskazywał pośrednio na ich kompetencje i zakres działania. Na pierwszym miejscu stawiał starania o wzbogacanie zbiorów. Polegały one głównie na pozyskiwaniu ofiarodawców materiałów bibliotecznych, takich jak rękopisy, druki, obrazy, ryciny, mapy, numizmaty, instrumenty astronomiczne i matematyczne oraz okazy przyrodnicze. Do tej sfery poczynań należały też zabiegi o pieniądze przeznaczane na nabywanie materiałów bibliotecznych. Protobibliotekarze uczestniczyli też bezpośrednio w zakupach książek na targach i aukcjach i oni podejmowali decyzje finansowe w tym zakresie. Na tym najważniejszym polu wyróżniał Hanow wielu protobibliotekarzy, zwłaszcza tych, którzy przez wiele lat sprawowali swe funkcje.

Oto kilka przykładów, ukazujących troskę i starania protobibliotekarzy o wzbogacanie zbiorów Biblioteki. Chr. Schroeder przyciagał do grona wspomagających książnicę nie tylko mieszkańców Gdańska, ale także osoby spoza tego miasta, a nawet spoza Polski, uzyskując tą drogą cenne materiały, w tym obrazy, numizmaty i okazy przyrodnicze. Z kolei B. Engelcke zasłużył się korzystnymi zakupami książek na aukcjach w Gdańsku i Królewcu. Udało mu się ponadto, jako pierwszemu z protobibliotekarzy, otrzymać od Marka Pelsa z Groningen dar pieniężny w wysokości 100 florenów. Ta forma wspomagania Biblioteki była dla celowego gromadzenia i uzupełniania zbiorów bardziej dogodna od przypadkowych darów i dlatego została przez Hanowa zaakceptowana. Przy J.E. Schmiedenie też jest wzmianka o darach pieniężnych, a także informacja o kolejnych ofiarodawcach i wzbogaceniu kolekcji przyrodniczej o głowę wieloryba. Znaczne środki finansowe pozyskali D. Schlieff oraz G. Reyger, a ten ostatni zasłużył się dodatkowo licznymi i cennymi zakupami książek. Za wzbogacanie zbiorów wyróżnił też Hanow J.G. Diesseldorffa (nabył cenne publikacje), A. Groddecka (uzupełnił kolekcję Engelcków, pozyskał dzieła G. Lengnicha i poszerzył znacznie galerię obrazów), A. Rosenberga (wprowadził do zbiorów prace wybitnych gdańskich uczonych, J. Heweliusza, J.T. Kleina, J.F. Breyna, a także dalsze portrety i albumy rycin), J.S. Boemelna (zdobył przychylność mecenasów ofiarujących pieniądze i książki, czego przykładem był K.E. Nimsgart). Analizując zapisy w księdze inwentarzowej, znajdujemy potwierdzenie opinii formułowanych przez Hanowa pod adresem protobibliotekarzy jako troskliwych opiekunów i dobrodziejów Biblioteki. W zakresie gromadzenia zbiorów działali oni kompetentnie, rozsądnie wydawali publiczne fundusze, mądrze dobierali materiały biblioteczne, wykazujac przy tym znajomość potrzeb miejscowego środowiska szkolnego i naukowego ${ }^{10}$.

Protobibliotekarze nie ograniczali się do starań o pozyskiwanie materiałów bibliotecznych i środków finansowych do ich nabywania. W kilku przypadkach dawali oni osobiście przykład ofiarności na rzecz Biblioteki, co Hanow zauważył i odpowiednio odnotowal. W tej dziedzinie wyróżnił A. i B. Engelcków, którzy przekazali Bibliotece własne, bardzo bogate i cenne zbiory, w tym i eksponaty 
muzealne (np. nagrobna statua), odznaczające się wysokimi walorami poznawczymi i zabytkowymi. Szczegółowo zostały opisane dary książek, obrazów i pieniędzy, dokonane przez Chr. Schroedera, J.Z. Ferbera, D. Schlieffa, J.E. Schmiedena, A. Rosenberga i J.G. Diesseldorffa. Przypomniịmy, że podobną ofiarnością na rzecz Biblioteki wykazał się też Hanow.

Niemałe były zasługi protobibliotekarzy w dziedzinie poczynań organizacyjnych, co również mocno wyeksponował Hanow, znający się na pracy bibliotecznej. $\mathrm{Na}$ tym polu wyróżnił się J.E. Schmieden. Za jego kadencji opracowany został szczegółowy regulamin udostępniania zbiorów, ogłoszony drukiem i wywieszony przy wejściu do Biblioteki ${ }^{11}$. On postarał się o stałe dochody finansowe $z$ kasy miejskiej, przeznaczając z nich 100 florenów rocznie na opłacanie bibliotekarza. Dzięki jego zabiegom drukarnia miejska została zobowiązana do dostarczania Bibliotece wszystkich tłoczonych tam publikacji, o co dopominał się już w 1660 roku A.Engelcke ${ }^{12}$. Ponadto własnym sumptem wyposażyl on ksiażnicę w nowe szafy, stoły i ławy, ozdobił sale barwnymi obiciami i zadbał o miękkie siedzenia w pomieszczeniu, gdzie odbywały się spotkania dyskusyjne. Z kolei D. Schlieff zajął się adaptacją nowo pozyskanej sali byłego Collegium Anatomicum, w której lokowano wpływające materiały biblioteczne. On też przeprowadził akcję sprzedaży aukcyjnej dubletów a uzyskane w ten sposób pieniądze (700 florenów w 1694 roku) wykorzystał na zakup nowych ksiażek ${ }^{13}$. Chr.G. Schroeder wiele uwagi poświęcił odnowieniu i przebudowie pomieszczeń bibliotecznych. Położono wówczas marmurową posadzkę, powiększono okna, połączono drzwiami wszystkie sale, wykonano nowe szafy. Idąc za przykładem D. Schlieffa, też zajął się racjonalną gospodarką dubletami i materiałami zbędnymi. W 1753 roku zorganizował sprzedaż tych materiałów a uzyskane dochody przeznaczył na zakup potrzebnych książek. Nabyto wówczas m.in. wydany w Lipsku przez J.H. Zedlera "Universal-Lexicon" w 67 tomach.

Stosunkowo mało miejsca poświęcił Hanow na opisanie zasług w zakresie porządkowania i opracowania zbiorów. Tego rodzaju działalność nie była wówczas wyraźnie potrzebna i rozwijana. Zbiory narastały wprawdzie szybko, ale przez długi czas wystarczającym przewodnikiem po nich był inwentarz, zapoczątkowany przez Daniela Asaricusa w 1596 roku i kontynuowany przez kolejnych bibliotekarzy, niekiedy też ręką protobibliotekarzy. Próby sporządzenia katalogu podjęto prawdopodobnie z początkiem XVII wieku, ale ich wyniki nie zachowały się ${ }^{14}$. Przełomu w tej dziedzinie dokonat $\mathrm{A}$. Engelcke, który osobiście zabrał się do porządkowania i katalogowego opracowania wszystkich zbiorów. W wyniku kilkuletniej pracy około 1658 roku powstał Catalogus universalis Bibliothecae Gedanensis in suas classes distributus. Był to katalog działowy, opatrzony w indeksy alfabetyczne, metodą i wykonaniem odpowiadający stanowi wiedzy i praktyki bibliotekarskiej w Europie połowy XVII wieku. Katalogiem Engelckego posługiwano się jeszcze w XVIII stuleciu, a w kontynuacjach stosowano wprowadzony tam schemat podziału i klasyfikacji $^{15}$.

Poczynania katalogowe A. Engelckego długo nie mogły znaleźć naśladowców. Nie wiemy, jaki był udział A. Groddecka w pracach Hanowa nad katalogiem alfabetycznym, który powstawał od 1728 roku $^{16}$. Sprawą opracowania zbiorów 
interesował się J.H. Broen i on zajął się uzupełnianiem katalogu Engelckego. Natomiast Chr. Schroeder porządkował materiały biblioteczne, wyłączył rękopisy i wydzielił w osobne miejsce zbiory prywatne.

$Z$ rozprawy Hanowa można też wyczytać inne informacje o protobibliotekarzach gdańskich XVII i XVIII wieku. Wynika z niej, że funkcję tę sprawowali członkowie Collegium Scholarchale, którzy wykazywali zainteresowanie ksiązką, nawet o charakterze bibliofilskim, np. A. Engelcke, J. Schrader, J.E. Schmieden, G. Reyger, S.G. Schumann, A. Groddeck. Wielu z nich cieszyło się wysokim uznaniem Rady Miasta i otrzymało stanowisko burmistrza urzędującego. Funkcja protobibliotekarza nie była ściśle określona czasowo. Sprawowano ją najczęściej do 5 lat (11 osób), do 10 lat urząd ten piastowały dwie osoby, a ponad 10 lat - pięć osób. Najdłużej byli protobibliotekarzami A. Rosenberg (19 lat), D. Schlieff (14 lat), Chr. Schroeder (12 lat), J.E. Schmieden i G. Reyger (po 11 lat). Do śmierci urząd ten sprawowało 5 osób.

Rozprawę zamknał Hanow uwagami na temat usprawnienia działalności Biblioteki. Odwołal się przy tym do przykładu Biblioteki Miejskiej w Hamburgu i poczynań dwóch znakomitych tamtejszych bibliotekarzy i bibliografów, Jana Chr. Wolfa oraz Pawła S. Schaffshausena. Pierwszy z nich wsławił się źródłowym dziełem „Monumenta typographica” (Hamburg 1740), drugi był autorem publikacji „Bibliographia antiquaria" (Hamburg 1760), obaj zaś przyczynili się do wzbogacenia zbiorów i postawienia na wysokim poziomie funkcjonowania Biblioteki Miejskiej w Hamburgu.

W zakresie opracowania zbiorów Hanow proponował zaprowadzenie katalogu alfabetycznego, jako sprawnego instrumentu wyszukiwania i kontrolowania książek. Hanow już w 1728 roku rozpoczął pracę nad takim katalogiem. Wskazał jednocześnie różne trudności towarzyszące takiemu przedsięwzięciu, np. opracowywanie dzieł anonimowych. W zakresie gromadzenia zbiorów widział potrzebę poszerzenia profilu i sięganie po publikacje dotyczące całej Polski oraz krajów z nią sąsiadujących. Wielką wage przywiązywał do gromadzenia zbiorów specjalnych, takich jak numizmaty czy okazy natury. Idąc za przykładem książnicy w Hamburgu, proponował zatrudnianie aż 8 osób z regularna płacą: 2 bibliotekarzy, 2 prowadzących ewidencję zbiorów, 2 kustoszy do pilnowania zbiorów i 2 pomocników. Do tego potrzebne byłyby stałe środki finansowe na opłacanie pracowników i pomnażanie zbiorów. Postulował ponadto stworzenie podstaw prawnych dla działalności Biblioteki.

Przedstawiona rozprawa zasługuje na uwagę z kilku względów. Jest ona świadectwem zainteresowań problematyką bibliotekarską w Gdańsku w dobie oświecenia. Zajmuje się pracownikami sfery bibliotecznej, którymi przed Hanowem nikt w Polsce $w$ ten sposób się nie interesował. Przynosi informacje o ludziach z urzędu troszczących się o biblioteki i przedstawia ich kompetencje, zakresy działania oraz wyniki starań i zabiegów. Zasługi ich wobec kultury i nauki w Gdańsku były bardzo duże i długo owocowały. Tylko nieliczni z nich zostali dostrzeżeni i wpisani w dzieje Gdańska. W „Słowniku pracowników książki polskiej” znaleźli się zaledwie A. Engelcke oraz J.E. Schmieden, ale nie jako protobibliotekarze, lecz bibliofile. Godzi się więc przypomnieć rozprawę Hanowa, aby tym samym przywrócić pamięć o zasługach protobibliotekarzy gdańskich XVII i XVIII wiekı 


\section{Przypisy}

${ }^{1}$ Z. Nowak, Stan i perspektywy badań nad historią książki na Pomorzu Gdańskim, "Studia o Książce" 17. Wroctaw 1988, s. 132-135; A. Żbikowska-Migoń, Historia ksiązki w XVIII wieku. Początki bibliologii, Warszawa 1989, s. 148-169; J. Korpala, Krótka historia bibliografii polskiej, Wroclaw 1986, s. 37-39.

${ }^{2}$ H. Rietz, Michał Krzysztof Hanow (1695-1773), przyrodnik, filozof, historyk, profesor Gimnazjum Akademickiego w Gdańsku, [W:] Wybitni Pomorzanie XVIII wieku. Szkice biograficzne, Wroctaw 1983 (Pomorze Gdańskie Nr 15), s. 71-78; K. Estreicher, Bibliografia polska, t. 18, Kraków 1901, s. 36-38.

${ }^{3} Z$. Nowak, Udzial miast Prus Królewskich i Książęcych w jubileuszu trzechsetlecia mynalezienia sztuki drukarskiej, „Biuletyn Biblioteki Jagiellońskiej” (w druku); tenże, Początki sztuki drukarskiej na Pomorzu w XV wieku, Gdańsk 1976, s. 41-43; Z.L. Pszczółkowska, Custodes librorum Gedanensium, „W kręgu książki" nr 12, Gdańsk 1989, s. 65-66; O. Günther, K. Kleefeld, Die Danziger Stadtbibliothek. Ihre Entwicklung und Ihr Neubau, Danzig 1905, s. 9.

${ }^{4}$ Annales Gymnasiastici et typographici Gedanenses, Bibl. Gd. PAN, sygn. Ms. 505.

${ }^{5}$ T. Węsierska-Biernatowa, J. Czaplicka, M. Sławoszewska, Archiwum miasta Gdańska. Przewodnik po zespołach 1253-1945, Warszawa 1970, s. 65-66. Akta Collegium Scholarchale $z$ lat 1603-1790 zachowaly się szczątkowo pod sygn. 300, 42.

${ }^{6}$ Z.L. Pszczółkowska, op. cit., s. 53, 61.

${ }^{7}$ Inwentarz ten jest przechowywany w Bibl. Gd. PAN, sygn. Cat. Bibl. 1.

${ }^{8}$ Z.L. Pszczółkowska, op. cit., s. 62; Słownik pracowników książki polskiej, Warszawa 1972, s. 794-795.

${ }^{9}$ Bibl. Gd. PAN, sygn. Oe $1088^{\circ}$ adl. 13; Oe $1178^{\circ}$ adl. 137; Oe $1248^{\circ}$ adl. 2. Zob też O. Günther, K. Kleefeld, op. cit., s. 5.

${ }^{10}$ Z. Nowak, Z dziejów Biblioteki, [W:] Biblioteka Gdańska Polskiej Akademii Nauk - dzieje i zbiory. Praca zbiorowa pod red. M. Babnis i Z. Nowaka, Wrociaw 1986, s. 17-18.

11 Tamże, s. 14-16.

12 Tamże, s. 22.

13 Tamże, s. 19.

14 Tamże, s. 23-24; P. Szafran, Katalog rękopisów Biblioteki Gdańskiej Polskiej Akademii Nauk. Uzupehnienie do tomów I-IV (Sygnatury 1-4258), Wroclaw 1988, s. 173-177.

${ }^{15}$ Z. Nowak, Z dziejów Biblioteki, s. 23-24.

${ }^{16}$ P. Szafran, op. cit., s. 177, sygn. Cat. Bibl. 12. 